\title{
Effect of Water Storage on Tooth Displacement in Maxillary Complete Dentures
}

\author{
Rafael Leonardo Xediek CONSANI ${ }^{1}$ \\ Marcelo Ferraz MESQUITA ${ }^{1}$ \\ Simonides CONSANI ${ }^{2}$ \\ Lourenço CORRER SOBRINHO ${ }^{2}$ \\ Manoel Damião SOUSA-NETO ${ }^{3}$
}

\author{
${ }^{1}$ Department of Prosthodontics and Periodontics; ${ }^{2}$ Department of Restorative Dentistry, \\ Faculty of Dentistry of Piracicaba, State University of Campinas (UNICAMP), Piracicaba, SP, Brazil \\ ${ }^{3}$ Department of Endodontics, School of Dentistry, University of Ribeirão Preto (UNAERP), Ribeirão Preto, SP, Brazil
}

\begin{abstract}
The purpose of this study was to investigate the effect of water storage at $37^{\circ} \mathrm{C}$ ( 1 week, 1 month and 3 months) on tooth displacement in maxillary complete dentures. Ten maxillary dentures were constructed with Clássico acrylic resin using the conventional method of packing in metallic flasks. Metallic reference pins were placed in the incisal border of the central incisors (I), labial cusp of the first premolars (PM), and mesiolabial cusp of the second molars (M). Twelve hours after final flask closure, the acrylic resin was cured in water at $74^{\circ} \mathrm{C}$ for $9 \mathrm{~h}$. The flasks were removed from the thermo-polymerizing unit after water-cooling and the dentures were deflasked, finished and stored in water at a temperature of $37^{\circ} \mathrm{C}$ for 1 week, 1 month and 3 months. At deflasking and at the water storage intervals, the I-I (incisor to incisor), PM-PM (pre-molar to pre-molar), and M-M (molar to molar) transversal distances, and LI-LM (left incisor to left molar) and RI-RM (right incisor to right molar) anteroposterior distances were measured using an optical microscope with $0.0005 \mathrm{~mm}$ accuracy. Data were submitted to ANOVA and Tukey's test (5\%). Comparing the evaluation periods for each individual transversal and anteroposterior reference point, no statistically significant differences were observed among deflasking and the water storage intervals for I-I, PM-PM, M-M and RI-RM distances ( $>00.05)$. For LI-LM, however, deflasking values were statistically different from those of 1-week, 1-month and 3-month water storage intervals $(\mathrm{p}<0.05)$, which, in turn, did not differ statistically to each other ( $>0.05$ ). These results confirm the complexity of tooth displacement in complete dentures. From a clinical standpoint, the difference observed in LI-LM distance after water storage would not be detected by the patients during clinical use.
\end{abstract}

Key words: maxillary denture, water immersion, tooth displacement.

\section{INTRODUCTION}

Since the introduction of acrylic resin in Dentistry in 1937, a certain lack of dimensional accuracy has been accepted as one of the disadvantages of complete denture construction, resulting from the unavoidable denture base shrinkage during acrylic resin polymerization $(1,2)$.

Loss of retention and stability of dentures under clinical conditions is caused by dimensional changes that occur in the acrylic resin base due to undesirable warpage and distortion (3) upon resin base water loss or uptake, stress release and base flexural fatigue (4-6).
Water sorption seen in clinical use following denture processing occurs during the first three months, and the consequent expansion partly compensates the curing shrinkage (7). As a result, water balance and dimensional stability of the denture base are frequently attained (8). Good wetting characteristics of the denture base are important because materials with different surface energies have distinct wettabilities (9). According to the diffusion theory for assessing the quantitative aspects of water sorption kinetics, the diffusion coefficient governs water sorption rate and the time required to reach equilibrium, which is also proportional to the thickness of the specimen (10). This suggests that 
the denture should fit better after water uptake than immediately after processing because the shape of oral tissues remains the same (11).

A previous study showed that the dimensional changes of light-cured, heat-cured and self-cured denture base resins stored in distilled water for 7 days at $37^{\circ} \mathrm{C}$ differed to each other (12). Conversely, the linear dimensional changes were similar in all resin brands after $30-, 60$ - and 90 -day water storage at $37^{\circ} \mathrm{C}$. These changes were minimal and not clinically detectable (13).

Measurements made after immersion in water at room temperature for $1 \mathrm{~h}, 1$ day and 1 week showed little dimensional changes using the continuous-injection technique, whilst the trial-pack technique had no influence. The findings also showed that these changes were influenced by palate shape (5).

Water saturation of both dry heat and wet heatprocessed dentures was relatively low due to their high initial water content. Thus, the linear expansion associated with water sorption did not entirely compensate the processing shrinkage of dry and wet heat-processed dentures, and did not demonstrate statistically significant difference in shrinkage (6). A recent study showed that the association between gypsum or silicone investment materials and water storage did not alter the majority of the distances among teeth (14).

The purpose of this study was to investigate the effect of water storage at $37^{\circ} \mathrm{C}$ ( 1 week, 1 month, and 3 months) on tooth displacement in maxillary complete dentures cooled in the water bath of the curing cycle.

\section{MATERIAL AND METHODS}

Ten maxillary dentures were constructed from similar stone casts simulating an arch without irregularities in the alveolar ridge crest.

A 2-mm-thick wax denture base-plate was prepared on the respective cast. The height of the occlusion wax rims was $20 \mathrm{~mm}$ in the labial sulcus of the cast and $10 \mathrm{~mm}$ in the second molar region. The upper stone cast was mounted on a Mondial 4000 semiadjustable articulator (Bio-Art Dental Products, São Carlos, SP, Brazil) with the wax-rim interocclusal relation settled according to the teeth of the lower stone cast, with the following references: intercondilar distance in $\mathrm{M}$, Bennett angle at $15^{\circ}$ and condilar guide at $30^{\circ}$.

In order to accurately mount all dentures on the semi-adjustable articulator, similar V-shaped notches were carved in the base of the upper stones casts.

The arrangement of the left anterior teeth started with the carved wax-rim to serve as a guide for the central and lateral incisors and canine. The same procedure was employed in the right hemi-arch. The posterior teeth were arranged starting with the first premolar until the second molar. The same procedure was used in the right hemi-arch. Tooth arrangement for interocclusal relationship was anterior vertical overlap and posterior Angle class I.

Metallic reference pins were placed in the incisal border of the central incisors, labial cusp of the first premolars and mesiolabial cusp of the second molars. The maxillary dentures were flasked conventionally in Herodent Soli-Rock dental stone (Vigodent, Rio de Janeiro, RJ, Brazil), using a standard metallic flask (J. Safrany Metallurgy Co., São Paulo, SP, Brazil). The waxed dentures were softened for $10 \mathrm{~min}$ in boiling water. Both halves of the flasks were separated, the wax was removed and the stone was cleaned with liquid detergent (Ypê, Qímica Amparo Ltda., Amparo, SP, Brazil) and boiling water. After bench cooling, one coat of Isolak sodium alginate (Clássico Dental Products, São Paulo, SP, Brazil) was used as mold separator.

A heat-cured polymethylmethacrylate-based acrylic resin was used (Clássico Dental Products). The material was prepared with a polymer: monomer ratio of 3:1 by volume, and the plastic dough was packed in the flasks under a final packing pressure of 1,250 kgf. Twelve hours after final flask closure, the acrylic resin was cured in water at $74^{\circ} \mathrm{C}$ for $9 \mathrm{~h}$ in a thermo-curing unit(Termotron Dental Products, Piracicaba, SP, Brazil). After processing, the flasks were cooled slowly in the water bath of the curing cycle at room temperature. After removal from the curing unit, the dentures were deflasked and polished.

The I-I (incisor to incisor), PM-PM (premolar to premolar) and MM (molar to molar) transversal distances, as well as the LI-LM (left incisor to left molar) and RIRM (right incisor to right molar) anteroposterior distances (Fig. 1) were measured using a a STM optical microscope (Olympus Optical Co., Tokyo, Japan) with $0.0005 \mathrm{~mm}$ accuracy. Thereafter, the dentures were stored in water at $37^{\circ} \mathrm{C}$ for periods of 1 week, 1 month and 3 months. After water storage, all distances were measured again in the same manner as that used at deflasking. Data were submitted to ANOVA and Tukey's test at 5\% significance level. 


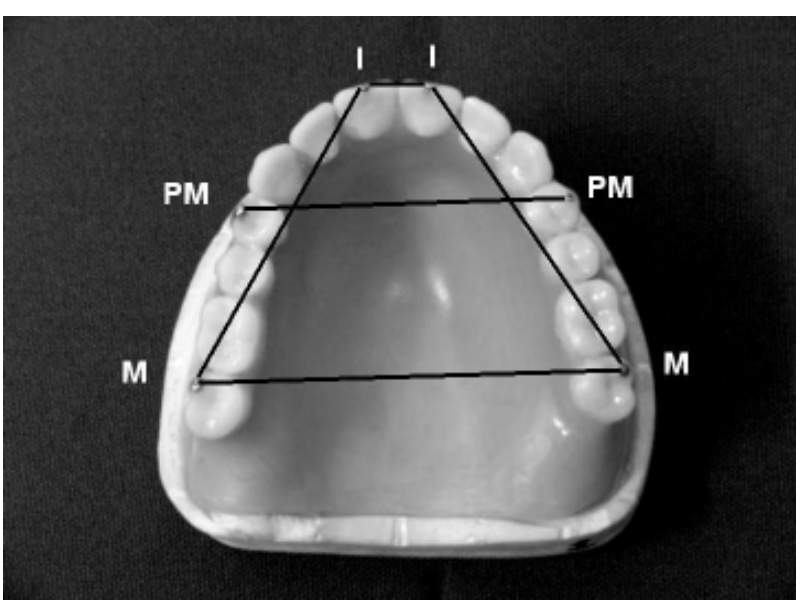

Figure 1. Transversal and anteroposterior distance reference points.

\section{RESULTS}

Table 1 (last column) shows that average tooth displacement was statistically similar in all evaluated periods ( $p>0.05$ ). Comparing the evaluation periods for each individual transversal and anteroposterior reference point, no statistically significant differences were observed among deflasking and the water storage intervals for I-I, PM-PM, M-M and RI-RM distances (p>0.05). For LI-LM, however, deflasking values were statistically different from those of 1-week, 1-month, and 3-month water storage intervals $(\mathrm{p}<0.05)$, which, in turn, did not differ statistically to each other ( $\mathrm{p}>0.05$ ).

\section{DISCUSSION}

Previous studies have demonstrated that the expansion caused by water sorption in moist heat-cured resin bases compensates, in part, the shrinkage that occurs during denture curing $(1,7)$.

The divergent results of several investigations make difficult to evaluate the effect of water sorption on tooth displacement. Resin base water sorption during clinical use and the consequent vertical dimensional changes may affect denture occlusion (10). The expansion of the horizontal and vertical planes after water sorption causes changes in the centric occlusion due to tooth displacement. Although vertical dimension reduction is small (1), it may cause discomfort to the patient.

In this study, expansion was expected to occur when the deflasked dentures were immersed in water because water sorption by acrylic resin is a wellestablished event $(9,10,11,13)$. However, the results showed that considering average tooth displacement among the evaluation periods, irrespectively of the transversal and anteroposterior reference points, no statistically significant difference was observed $(\mathrm{p}>0.05)$ between deflasking and the water storage intervals (Table 1). These results are not consistent with those of a previous study, which showed that the monomer remaining immediately after specimen deflasking affects water uptake level (13). However, the same study showed no significant difference in linear dimension of the acrylic resin specimens due to storage in water for up to 3 months. The findings of another investigation disclosed that acrylic resin bases showed no significant dimensional changes after storage in water for 30 days (15). Similar results were observed in this study when the transversal teeth displacement was assessed at the water storage intervals (Table 1 ).

Table 1. Means \pm SD of tooth displacement $(\mathrm{mm})$ for deflasking and water storage intervals based on transversal and anteroposterior distance reference points.

\begin{tabular}{lcccccc}
\hline $\begin{array}{l}\text { Evaluation } \\
\text { periods }\end{array}$ & \multicolumn{5}{c}{ Tooth distance $(\mathrm{mm})$} \\
\cline { 2 - 7 } & $\mathrm{I}-\mathrm{I}$ & PM-PM & M-M & RI-RM & LI-LM & Average \\
\hline Deflasking & $7.20 \pm 0.30 \mathrm{a}$ & $39.81 \pm 0.32 \mathrm{a}$ & $52.83 \pm 0.84 \mathrm{a}$ & $37.44 \pm 0.80 \mathrm{a}$ & $34.91 \pm 0.54 \mathrm{a}$ & $34.44 \pm 15.11 \mathrm{a}$ \\
1 week & $7.21 \pm 0.31 \mathrm{a}$ & $39.67 \pm 0.35 \mathrm{a}$ & $52.65 \pm 0.82 \mathrm{a}$ & $38.12 \pm 1.25 \mathrm{a}$ & $33.85 \pm 1.25 \mathrm{~b}$ & $34.30 \pm 15.10 \mathrm{a}$ \\
1 month & $7.26 \pm 0.23 \mathrm{a}$ & $39.75 \pm 0.28 \mathrm{a}$ & $52.80 \pm 0.73 \mathrm{a}$ & $37.99 \pm 1.03 \mathrm{a}$ & $34.03 \pm 0.62 \mathrm{~b}$ & $34.37 \pm 15.10 \mathrm{a}$ \\
3 months & $7.27 \pm 0.22 \mathrm{a}$ & $39.81 \pm 0.28 \mathrm{a}$ & $52.71 \pm 0.71 \mathrm{a}$ & $38.05 \pm 1.02 \mathrm{a}$ & $34.08 \pm 1.02 \mathrm{~b}$ & $34.38 \pm 15.09 \mathrm{a}$ \\
\hline
\end{tabular}

Means followed by different letters in each column indicate statistically significant difference at 5\%. 
Comparing the evaluation periods for each individual transversal and anteroposterior reference points, there was no statistically significant difference ( $>0.05$ ) among deflasking values and the values obtained after 1-week, 1-month and 3-month water storage for all transversal distances (Table 1). A previous work has shown greater linear dimensional changes due to water uptake for bench-cooled denture bases than for those cooled slowly in water baths (6). Dimensional changes by water sorption cause expansion apparently due to water penetration within acrylic resin molecules $(11,16)$, resulting in a plasticizing effect (17) when absorbed during polymerization or immersion in water (18).

It may be speculated that the similar tooth displacement observed among the water storage intervals was due to similar amount of water uptake by volume of the acrylic mass, independently of the amount of residual monomer in the denture base during initial storage. Because the initial water content in wet heatprocessed dentures is high (6), the consequent low saturation during water storage allowed similar stress release by denture bases kept under the same storage conditions, resulting in similar tooth displacment levels.

Conversely, for the LI-LM anteroposterior distance, deflasking values differed statistically from those obtained after storage in water for 1 week, 1 month and 3 months $(p<0.05)$. The water storage intervals did not show statistically significant difference to each other $(p>0.05)$ (Table 1$)$. This result suggests that the displacement of denture teeth due to acrylic resin base water sorption involves other factors occurring during the denture processing, such as base thickness, geometrical palate form, closure flask pressure, cooling method of the flask, different stresses released in different parts of the denture and mesiodistal tooth contact $(12,14,19,20)$.

The investment material is also an important factor to be regarded in denture processing. A recent work showed that the association between gypsum or silicone investment materials and water storage did not alter the distances between teeth, except for the PM-PM distance after 3-month water storage of the silicone investment material (14).

In the present study, there was evidence of similar water sorption by the denture base at the evaluation periods because the dimensional changes after water storage were similar to those occurred at deflasking. Among five transversal and anteroposterior distance reference points, statistically significant difference was found only for the LI-LM distance.

Within the limitations of an in vitro study, these results are relevant to confirm the complexity of the tooth displacement in the complete dentures. From a clinical standpoint, the difference observed in LI-LM distance after water storage would not be detected by the patients during clinical use. Further studies are necessary to investigate denture processing methods that can yield minimal tooth displacement.

\section{RESUMO}

Este estudo avaliou a movimentação dental sob influência da imersão em água ocorrida na armazenagem da prótese à temperatura de $37^{\circ} \mathrm{C}$. Foram confeccionadas 10 próteses totais superiores com resina acrílica Clássico pelo método convencional de prensagem em muflas metálicas. Pontos referenciais metálicos foram colocados nos dentes incisivos centrais (I), pré-molares (PM) e molares (M). Doze horas após a prensagem final, a resina acrílica foi polimerizada em água aquecida a $74^{\circ} \mathrm{C}$ por $9 \mathrm{~h}$. As muflas foram removidas da unidade polimerizadora após esfriamento da água e as próteses foram desincluídas, acabadas e armazenadas em água à temperatura de $37^{\circ} \mathrm{C}$ pelos períodos de 1 semana, 1 mês e 3 meses. A movimentação dos dentes foi verificada nas distâncias transversais I-I, PM-PM e M-M e ântero-posteriores IE-ME e ID-MD após demuflagem e nos intervalos de armazenagem em água, com microscópio comparador óptico com precisão de 0,0005 mm. Os resultados foram submetidos à análise de variância e ao teste de Tukey (5\%). Comparando-se os períodos de avaliação para cada ponto de referência transversal e ântero-posterior, não houve diferença estatisticamente significante $(\mathrm{p}>0.05)$ entre os valores pósdemuflagem e após os intervalos de armazenamento em água para as distâncias I-I, PM-PM, M-M e RI-RM. Para o ponto LI-LM, entretanto, os valores de demuflagem foram estatisticamente diferentes daqueles observados após estocagem em água por 1 semana, 1 mês e 3 meses $(\mathrm{p}<0.05)$, os quais, por sua vez, não diferiram estatisticamente uns dos outros $(p>0.05)$. Esses resultados confirmam a complexidade da movimentação dos dentes em próteses totais. Do ponto de vista clínico, a diferença observada para a distância LI-LM após a armazenagem em água não seria percebida pelos pacientes durante o uso clínico.

\section{REFERENCES}

1. Skinner EW, Cooper EM. Physical properties of denture resins: Part I. Curing shrinkage and water sorption. J Am Dent Assoc 1943;30:1845-1852.

2. Lechner SK, Thomas GA. Changes caused by processing complete mandibular dentures. J Prosthet Dent 1994;72:605613.

3. Stebner CM. Report: Part II. An appraisal of recent significant developments in the practice of general dentistry. J Prosthet Dent 1957;7:828-832.

4. Woelfel JB, Paffenbarger GC. Dimensional changes occurring 
in artificial dentures. Int Dent J 1959;9:451-460.

5. Sykora O, Sutow EJ. Posterior palatal seal adaptation: influence of processing, palate shape and immersion. J Oral Reabil 1993;20:19-31.

6. Wong DMS, Cheng LYY, Chow TW, Clark RKF. Effect of processing method on the dimensional accuracy and water sorption of acrylic resin dentures. J Prosthet Dent 1999;81:300-304.

7. Mowery WE, Burns CL, Dickson G, Sweeney WT. Dimensional stability of denture base resins. J Am Dent Assoc 1958;57:345-353.

8. Sweeney CM. Acrylic resin in prosthetic dentistry. Dental Clin N Amer 1958;29:7-10.

9. Zissis A, Yannikakis S, Jagger RC, Waters MG. Wettability of denture materials. Quintessence Int 2001;31:457-462.

10. Ristic B, Carr L. Water sorption by denture acrylic resin and consequent changes in vertical dimension. J Prosthet Dent 1987;58:689-693.

11. Campbell RL. Effects of water sorption on retention of acrylic resin denture bases. J Am Dent Assoc 1956;52:448454.

12. DaBreo EL, Herman P. A new method of measuring dimensional change. J Prosthet Dent 1991;65:718-722.

13. Dixon DL, Breeding LC. Linear dimensional variability of three denture base resins after processing and in water storage. J Prosthet Dent 1992;67:196-200.

14. Boscato N, Consani RLX, Consani S, Cury, AADB. Effect of investment materials and water immersion time on tooth movement in complete denture. Eur J Prosthodont Rest Dent 2005;13:164-169.

15. Anderson CG, Schulte JK, Arnold TG. Dimensional stability of injection and conventional processing of denture base acrylic resin. J Prosthet Dent 1988;60:394-398.

16. Anusavice KJ. Phillips' science of dental materials. 11th ed. Philadelphia: Elsevier; 2003.

17. Sadamori S, Ishii T, Hamada T. Influence of thickness on the linear dimensional change, warpage, and water uptake of a denture base resin. Int J Prosthodont 1997;10:35-43.

18. Teraoka F, Takahashi J. Controlled polymerization system for fabricating precise dentures. J Prosthetic Dent 2000;83:514-520.

19. Consani RLX, Mesquita MF, Sinhoreti MAC, Consani S. Influence of deflasking delay time on the displacement of maxillary denture teeth. J Appl Oral Sci 2003;11:332-336.

20. Consani RLX, Domitti SS, Mesquita MF, Consani S. Effect of packing types on the dimensional accuracy of denture base resin cured by the conventional cycle in relation to postpressing times. Braz Dent J 2004;15:63-67.

Accepted July 2, 2004 